\title{
Kesiapan Petugas dalam Peralihan Dokumen Rekam Medis Manual ke Paperless pada Unit Rekam Medis Puskesmas Kedungmundu Kota Semarang
}

\author{
Preparation of Officers in Transfer Of Manual Medical Recording \\ Documents to Paperless in The Medical Record Unit of Kedungmundu \\ Public Health Center, Semarang
}

\author{
Anike Yulis $\mathbf{M}^{1}$, Retno Astuti, $\mathbf{S}^{1}$, Fitria Wulandari ${ }^{1}$ \\ ${ }^{1}$ Fakultas Kesehatan Universitas Dian Nuswantoro Semarang, Jawa tengah, \\ Indonesia \\ Korespondensi Author : fitria.wulandari@dsn.dinus.ac.id
}

Penyerahan : 23-11-2020, Perbaikan : 03-12-2020, Diterima : 25-12-2020

\begin{abstract}
Background Document management using a computer-based / electronic system in the health sector which is becoming a global trend is electronic medical records (RME) which is a sub-health information system that has begun to be widely implemented in Indonesia, limited storage space for medical records and home efforts. In order to improve the quality of service, hospital management or health service providers choose to implement Electronic Medical Records. The purpose of this study was to determine the readiness of officers during the transition of paper-based medical records to computerbased medical records or electronic medical records (RME). This type of research was descriptive with a qualitative approach, while the data collection method was carried out by observation and interviews. directly to the officers in the medical records section at Public Health Center in the city of Semarang Result: Based on the results of interviews with officers and observations at the research site, it was found that at the Kedungmundu Puskesmas the paperless system at SIMPUS still often occurred errors caused by existing facilities and infrastructure but not optimal, namely the internet network is bad, while the internet in SIMPUS sometimes gets errors from the Distric of health, besides that the staff at the health center, which number 5 people are also still not familiar with the use of simpus, therefore further training is needed on the use of simpus, and the need for crosschecks. from Distric of health to Public Health Center to ensure that simpus can run well in Public Health Center.
\end{abstract}

Keywords : readiness, Transition, elektonic medical record

\section{ABSTRAK}

Pengelolaan dokumen dengan menggunakan sistem yang berbasis komputer/elektronik di sektor kesehatan yang sedang menjadi trend global adalah rekam medis elektronik (RME) yang merupakan sub sistem informasi kesehatan yang mulai banyak diterapkan di Indonesia, Adanya keterbatasan ruang penyimpanan rekam medis dan juga upaya rumah sakit untuk meningkatkan kualitas pelayanan maka manajemen rumah sakit atau tepta pelayanan kesehatan memilih untuk menerapkan Rekam Medis Elektronik. Tujuan dari penelitian ini adalah untuk mengetahui kesiapan petugas dalam masa peralihan dokumen rekammedis berbasis kertas (paper based) ke rekam medis berbasis komputer atau rekam medis elektronik (RME) Jenis penelitian adalah deskriptif dengan pendekatan kualitatif, sedangkan metode pengambilan data dilakukan dengan cara observasi dan wawancara secara langsung pada petugas di bagian rekam medis di Puskesmas Kedungmundu di kota semarang. Berdasarkan hasil wawancara kepada petugas dan

Jurnal Dunia Kesmas Vol. 10 No. 1, Januari 2021, hal. 1-9

ISSN 2301-6604 (Print), ISSN 2549-3485 (Online)

http://ejurnalmalayahati.ac.id/index.php/duniakesmas/index 
observasi di tempat penelitian diperoleh hasil bahwa di Puskesmas Kedungmundu sistem paperless di SIMPUS masih sering terjadi eror yang disebabkan oleh sarana dan prasarana yang sudah ada namun belum maksimal yaitu jaringan internet yang buruk sedangkan intenet dalam SIMPUS terkadang eror dari Dinas, selain itu petugas di puskesmas yang berjumlah 5 orang juga masih belum familiar terhadap penggunaan simpus, oleh karena itu diperlukan pelatihan lebih lajut mengenai penggunaan simpus, dan perlunya chrosschek dari Dinas Kesehatan ke Puskesmas untuk memastikan bahwa simpus dapat berjalan dengan baik di Puskesmas.

\section{Kata Kunci: kesiapan, peralihan, rekam medis elektronik}

\section{PENDAHULUAN}

Puskesmas adalah fasilitas pelayanan kesehatan yang menyelenggarakan upaya kesehatan masyaraka dan upaya kesehatan perseorangan tingkat pertama, dengan lebih mengutamakan promotive dan preventif di wilayah kerjanya. (Kemenkes RI 2020) Puskesmas Kedungmundu berada di kecamatan Temabalang Kota semarang dengan wilayah kerja meliputi Kelurahan Kedungmundu, Tandang, Jangli, Sendangguwo, Sendangmulyo, Sambiroto, dan Kelurahan Mangunharjo. Dengan total luas wilayah ke tujuh Kelurahan tersebut adalah $2.135,96 \mathrm{~km}^{2}$, dengan jumlah penduduk Wilayah Kerja Puskesmas Kedungmundu Kecamatan Tembalang berdasarkan data Kecamatan Tembalang pada tahun 2017 berjumlah 127.776 jiwa, dengan jumlah Rumah Tangga 36.147 Kepala Keluarga. Angka kepadatan penduduk rata-rata di wilayah

Kedungmundu127.776 jiwa/km². dalam melaksanakan pelayanan kepada masyarakat di wilayah kerjanya puskesmas kedungmundu menggunakan sistem pencatatan dokumen rekam medis secara manual ( paper based). Menurut Permenkes nomor 269/MENKES/PER/III/2008 pasal 1 ayat (1), Rekam medis adalah berkas yang berisikan dokumen dan catatan mengenai identitas pasien, pemeriksaan, pengobatan dan tidakan pelayanan lain yangtelah diberikan kepada pasien. (Samandari, Chandrawila S, and Rahim 2017) Rekam medis dalam pelaksanaannya tidak terlepas dari media sebagai tempat menyimpan atau meulis hasil sebagai bukti dan dokumen pelayanan kesehatan bagi pasien. Secara umum dokumen rekam medis berbasis kertas (paper based) terdiri dari : formulir rekam medis, clip atau fastener, pembatas dan folder rekam medis. Dalam perkembangannya sejalan dengan perkembangan teknologi informasi yang terjadi sekarang ini memungkinkan berkembangnya suatu metode baru dalam mengelola dan menyimpan dokumen secara alektronik. Pengelolaan dokumen rekam medis secara elektronik, saat ini sedang menjdai trend global, selanjutnya pengelolaan dokumenrekam medis secara elektronik ini disebut dengan Rekam Medis Elektronik (RME).

Elektronik medical record atau RME merupakan bagian dari Elektronik health record yang telah banyak digunakan untuk menggantikan atau melengkapi rekam medis berbentuk kertas. RME adalah versi dari rekam medis yang dibuat menjadi elektronik yang memindahkan catatan -catatan atau formulir yang awalnya berbentuk kertas kedalam format elektronik. 
Perkembangan rekam medis elektronik di indonesia belum diatur secara khusus, namum dengan adanya dukungan permenkes NO 269 tahun 2008 tentang keabsahan RME sebagai bukti hukum memberikan harapan bagi perkembangan RME di Indonesia. Penerapan rekam medis elektronik diharapkan membantu meningkatkan kualitas pelayanan kepada pasien. Penilaian kesiapan pra implementasi RME akan membantu manajemen puncak untuk memilih apakah harus memulai implementasi RME atau menerapkan langkah awal yang murah ayang akan mempersiapkan Organisaasi mengantisipasi perubahan (Pribadi, Dewi, and Kusumanto 2018). Tujuan Rekam medis adalah menunjang tercapainya tertib administrasi dalam rangka upaya peningkatan mutu pelayanan kesehatan yang baik di tunjang dengan penyelenggaraan rekam medis yang baik pada setiap pelayanan kesehatan di rumahsakit.(Gemala Hatta 2013). Pada peleitian yang dilakukan sebelumnya mengena manfaat penerapan Rekam medis elektronik Oleh F. Erawantini, Dkk diperoleh hasil bahwa kelengkapan pengisian dokumen rekam medis elektronik sebanyak 67,84\%, lebih tinggi dibandingkan dengan kelengkapan pengisian dokumen rekam medis manual yang hanya mencapai 66,84\%. (REKAM MEDIS ELEKTRONIK: TELAAH MANFAAT DALAM KONTEKS PELAYANAN KESEHATAN DASAR 2013)

Dalam peta jalan sistem informasi kesehatan dijelaskan bahwa, Sistem informasi Kesehatan(SIK) adalah seperangkat tatanan yang meliputi data, informasi, indikator, prosedur, perangkat, teknologi, dan sumber daya manusia yang saling berkaitan dan dikelola secara terpadu untuk mengarahkan tindakan atau keputusan yang berguna dalam mendukung pembangunan kesehatan.(Kementerian Kesehatan 2015) Dalam pelaksanaannya SIK di adopsi dalam bentuk SIMPUS yang diterapkan di Puskesmas. menurut Peraturan Menteri Kesehatan no 31 tahun 2019 simpus adalah suatu tatanan yang menyediakan informasi untuk membantu proses pengambilan keputusan dalam melaksanakan manajemen Puskesmas dalam mencapai sasaran kegiatannya(Kemenkes RI 2019)

\section{METODE}

Penelitian ini dilakukan dengan metode deskriptif, dengan pendekatan crosssectional, metode pengumpulan data dilakukan dengan observasi dan wawancara langsung kepada petugas di puskesmas kedungmundu yang langsung menangani rekam medis berjumlah 5 (lima orang), object dalam penelitian ini adalah kesiapan petugas dalam peralihan penggunaan dokumen rekam medis manual ( paper based) ke dokumen rekam medis berbasis lektronik (RME)

\section{HASIL}

Berdasarkan hasil obeservasi dan wawancara kepada petugas, terdapat beberapa hal yang mempengaruhi kesiapan petugas dalam menggunakan Rekam medis elektronik (RME). Yaitu : Unit Rekam medis pasien yang terdiri dari beberapa bagian, antara lain : Pendaftaran pasien pada unit ini diterapkan beberapa aturan dalam pengelolaan dokumen rekam medis, antara lain (1) Sistem Penomoran Pada Puskesmas Kedungmundu menerapkan sistem penomoran Unit 
Numbering System (UNS), pada sistem penomoran ini setiap pasien yang datang berobat mendapatkan satu nomor rekam medis yang digunakan untuk satu kepala keluarga dan digunakan selamanya untuk kunjungan berikutnya di Puskesmas Kedungmundu (2) Sistem Penamaan Sistem penamaan di Puskesmas Kedubgmundu menggunakan nama asli pasien sesuai identitasnya, seperti KTP, KK, SIM. Sehingga mempermudah dalam memberikan pelayanan rekam medis kepada pasien yang datang berobat ke Puskesmas Kedungmundu.(3) Sistem Antrian Sistem antrian di customer service Puskesmas Kedungmundu untuk pendaftaran diloket dengan menggunakan fitur monitor antrian yang ada di SIMPUS. Antrian dibagi menjadi tiga, yaitu MTBS dan Lansia (A), KIA dan Gigi (B), Umum (C). Bagian Selanjutnya yang mempengaruhi kesiapan adalah Filing, di Puskesmas Kedungmundu, dapat di sampaikan beberapa informasi mengenai ruang filing, antara lain : (1) Sistem Penjajaran, Pada Puskesmas Kedungmundu menerapkan metode nomor langsung Straight Numerical Filing (SNF) yaitu suatu sistem penyimpanan dokumen rekam medis dalam rak dengan mensejajarkan berkas dokumen rekam medis secara berurutan sesuai dengan urutan nomor rekam medisnya baik DRM dalam wilayah maupun DRM luar wilayah, untuk DRM dalam wilayah dan luar wilayah menggunakan map DRM berwarna biru, sedangkan untuk DRM luar wilayah pada nomor Rekam Medisnya di angka depan terdapat angka 90 yang berarti DRM tersebut adalah DRM luar wilayah, penyimpanan DRM luar wilayah tidak digabung dengan DRM dalam wilayah, DRM luar wilayah memiliki rak sendiri untuk menyimpan DRM. (2) Sistem Penyimpanan, Dalam penyimpanan DRM, Puskesmas Kedungmundu menggunakan sistem penyimpanan secara Family Folder. Sistem penyimpanan Family folder yaitu, suatu sistem penyimpanan dengan cara menyatukan formulir rekam medis milik pasien kedalam map Family Folder yang didalamnya berisi DRM pasien satu kepala keluarga. Dokumen rekam medis yang disimpan kedalam rak penyimpanan tidak ditumpuk melainkan disusun landscape satu dengan yang lain. Dengan menggunakan sistem ini, para petugas tidak terlalu sulit untuk mencari DRM pasien yang berkunjung. Dapat mempermudah dan mempercepat pelayanan pasien.

(3) Retensi atau penyusutan dokumen rekam medis di Puskesmas Kedungmundu dilakukan dengan cara melihat tanggal kunjungan 5 tahun terakhir pasien yang datang berobat. (4) Koding \& Indeksing, Di Puskesmas Kedungmundu pengkodingan dilakukan di poli langsung oleh dokter yang menangani pasien dan menuliskan pada DRM pasien, kemudian setelah dokter tersebut menuliskan kode diagnosa pada dokumen rekam medis, petugas poli akan menginput kode diagnosa dan tindakan pasien ke dalam SIMPUS setelah semua pelayanan di Puskesmas selesai. Selain Unit rekam medis, faktor yang sangat mempengaruhi dalam kesiapan pelaksanaan peralihan ke dalam sistem rekam medis elektronik adalah Teknologi Informasi Berdasarkan observasi dan wawancara kepada petugas di Puskesmas Kedungmundu setiap komputer memiliki username dan password untuk menjaga keamanan data, tetapi username dan password 
tersebut hanya untuk 1 komputer, sehingga kurang informasi jika petugas salah memasukan data karena 1 komputer digunakan lebih dari 1 petugas. Sistem informasi juga dapat melakukan backup data yang memungkinkan data tidak hilang ketika terjadi error. Pemerintah kota semarang telah mengupayakan sebuah sistem dalam emndukung peralihan ke dokumen rekam medis elektronik, salah satunya adalah dengan menyediakan Sitem Informasi Puskesmas Online (SIP Online). Didalam dilakukan pencatatan pelayanankepada pasien, pencatatan hasil kegiatan oleh pelaksanan dicatat dalam buku-buku register yang berlaku untuk masingmasing program. Data tersebut kemudian direkapitulasikan ke dalam format laporan SIP yang sudah dibukukan dan akan disimpan di SIMPUS. Koordinator SIP di puskesmas menerima laporanlaporan dalam format buku dan print out pengisian SIP yang akan disimpan untuk arsip. Setelah diolah dan dianalisis kemudian dikirim ke Dinas Kesehatan Kota Semarang. Berdasarkan hasil observasi diatas, maka dapat dilakukan Analisis permasalahan berdasarkan faktor Man, money, methode, material, dan mechine (5 M), yaitu (a) Man; Berdasarkan teori, Man adalah petugas yang melakukan kegiatan pengelolaan rekam medis. Di Puskesmas Kedungmundu terdapat 5 petugas. Petugas harus melakukan pelatihan tentang sistem komputer dengan terampil agar pelayanan kepada pasien cepat dan memuaskan, berdasarakan keterangan yang diperoleh saat wawancara dengan petugas diketahui bahwa petugas belum sepenuhnya menguasai prosedur penggunaan SIP online, sehingga masih diperlukan pelatihan mengenai sistem baru yang di terapkan. (b) Material; Dari hasil pengamatan di Puskesmas Kedungmundu sarana dan prasarana sangat mendukung sistem paperless dalam SIMPUS dikomputer, namun sarana dan prasarana yang sudah ada di Puskesmas Kedungmundu sudah tersedia tetapi belum maksimal sehingga SIMPUS masih sering eror.(c) Methods; Di Puskesmas Kedungmundu sudah ada SOP/ Prosedur yang mengatur tentang sistem paperless yang terdapat di SIMPUS. Sistem paperless ini merupakan pengisian rekam medis pasien menggunakan komputer sehingga identitas pasien harus terisi lengkap agar data bisa tersimpan. Dan petugas sudah melakukan kinerja dengan baik sesuai dengan pedoman yang terdapat di SOP. (d) Machine; Di Puskesmas Kedungmundu rekam medis pasien sudah menggunakan sistem paperless yang terdapat dalam SIMPUS dikomputer. Sistem ini harus didukung jaringan internet yang baik, namun SIMPUS di Puskesmas Kedungmundu masih sering terjadi eror yang disebabkan oleh jaringan internet yang buruk dan saat listrik mati genset tidak otomatis menyala sehingga pelayanan kepada pasien bisa terhambat yang mengakibatkan pasien bisa menunggu terlalu lama. (e) Money Dana adalah salah satu hal yang paling berperan untuk mencapai pelaksanaan suatu sistem di Puskesmas agar terciptanya pelayanan yang baik dan cepat sesuai dengan yang diharapkan pasien. Jika petugas membutuhkan barang, petugas membuat laporan dan melaporkannya kepada petugas pengadaan. 


\section{PEMBAHASAN}

Pemanfaatan rekam medis elektronik akan memangkas alur pendaftaran pasien, serta antrian pasien, karena dengan penerapan rekam medis elektronik penyiapan dokumen akan lebih cepat, serta mengurangi terjadinya kesalahan medis, hal ini sesuai dengan tujuan penerapan RME menurut Kukafa, dkk (2007) dalam Pribadi,Y (2018) adalah meningkatkan mutu pelayanan kepada pasien, serta dapat meningkatkan efisiensi dan memangkas biaya, memudahkan penaihan pembayaran, menyediaka dokumen pasien, mengurangi hilangnya arsip data dan kesalahan medis (Pribadi, Dewi, and Kusumanto 2018). Beberapa faktor yang mempengaruhi sukses atau tidak nya penerapan RME dapat di nilai dari beberapa faktor, antara lain faktor man, money, mechine, methode dan money. Dari sisi manusia (man), di Puskesmas kedungmundu terdapat 5 (lima) orang yang bertugas dibagian rekam medis, petugas sudah mengetahui adanya sistem baru dalam penerapan rekam medis, namun mereka menyatakan masih memerlukan adanya pelatihan agar mudah dalam menjalankan RME dalam aktivitas pelayanan pasien, Menurut Shoolin (2010) dalam maha wirajaya (2020) pada tahap awal penerapan RME akan mengakibatkan pergeseran budaya yang semula manual (paper based) selanjutnya berubah menjadi elektronik, sehingga akan memiliki efek fisik dan fisiologis, menurut ajami dalam mahawijaya (2020) Pihak manajemen terutama pimpinan sebaiknya memberikan motivasi kepada pegawai/staff dalam penerimaan terhadap pelaksanaan RKM pada institusi, hal ini akan menjadi faktor penentu uatama dalam keberhasilan RME. Peningkatan pengetahuan petugas dapat dilakukan dengan mengadakan pelatihan terkait dengan sistem yang diterapkan pada puskesmas tersebut. Menurut harianja (2007) dalam Maha wijaya (2020) pelatihan dilakukan dengan tujuan untuk meningkatkan keahlian dan kemampuan seseorang, sehingga apabila terdapat kelemahan/kekurangan pada orang tersebut dapat segera dilakukan perbaikan/peningkatan (Maha Wirajaya and Made Umi Kartika Dewi 2020) selanjutnya dari sisi material, di Puskesmas Keedungmundu telah disediakan sarana prasarana dalam mendukung pelaksanaan RME, namun dalam pelaksanaannya masih ditemukan beberapa kendala, misalnya ketika sedang digunakan sistem mengalami eror.hal ini sejalan dengan penelitian yang dilakukan oleh anjani dan bagheritadi (2013) dalam Pribadi, Y (2018) bahwa beberapa hambatan yang sering dialami berhubungan dengan implementasi RME yaitu : gangguan alur kerja, khawatir tentang kemanan dan privacy data, komunikasi antar pengguna, dokter dan pasien (Pribadi, Dewi, and Kusumanto 2018) Kesiapan sarana prasarana terkait dengan pelaksanaan RME pada suatu instansi menjadi hal sangat penting, biasanya hal ini terkait dengan permasalahan keuangan atau anggaran, sehingga mengakibatkan keterbatasan dalam penyediaan infrastruktur yang dibutuhkan. Dalam penelitian yang dilakukan oleh Santoso dkk (2020), mengenai pengembangan rekam medis elektronik berbasis software as a service bagi dokter praktik mandiri, dokumen rekam medis elektronik 
harus dapat menyimpan dan menampilkan riwayat pasien terkait engan riwayat alergi, dan riwayat kunjungan pasien ke dokter(Santoso, Dian budi; Nuryati; Pramono 2020). Penyediaan infrastruktur oleh Dinas Kesehatan Kota semarang untuk pelaksanaan RME ini telah sejalan dengan penellitian yang dilakukan oleh sudirahayu (2016) dimana pada penelitian tersebut dijelaskan bahwa di RS RSUD Dr. H. Abdul Moeloek sudah siap. Hal ini juga sejalan dengan penelitian yang telah dilakukan oleh ridha afian (2020) di Puskesmas Ikur Koto Padang, bahwa pelaksanaan Elektronik Puskesmas belum optimal dipengaruhi oleh sumberdaya manusia yang belum terampil dan sarana prasarana yang kurang memenuhi.(Azyyati Ridha Alfian 2020). Faktor selanjutnya yang mempengaruhi pelaksanaan RME adalah Methode, di Puskesmas Kedungmundu sudah terdapat SOP yang mengatur tentang sistem RME (paperless ), dan petugas sudah melaksanakan SOP dengan baik. Hal ini sejalan dengan penelitian sebelumnya yang dilakukan oleh mahawijaya (2020) bahwa kegiatan monitoring dan reporting mempengaruhi kesiapan organisasi dalam melaksanakan RME.(Pribadi, Dewi, and Kusumanto 2018), Selain itu faktor yang mempengaruhi penerimaan penerapan RME di suatu organisasi adalah mesin (mechine) dalam hal ini pelaksanaan RME di Puskesmas Kedungmundu sudah berjalan sejalan dengan diterapkannya SIMPUS di Puskesmas tersebut. Pelaksanaan RME harus didukung oleh infrasrtuktur yang lain seperti internet dan kesiapan genset untuk mengantisipasi jika terjadi kematian listrik. Dalam pelaksanaanya jaringan internet di
Puskesmas Kedungmundu masih kurang stabil sehingga menyebabkan eror dan membuat waktu pelayanan pasien lebih lama, hal ini juga terjadi apabila terjadi pemadaman listrik, karena genset di Puskesmas belum bisa otomatis menyala apabila terjadi pemdaman listrik. Hal ini belum sejalan dengan tujuan pelaksanaan RME yaitu salah satunya memangkas waktu dan alur pelayanan kepada pasien. $\mathrm{Hal}$ ini sejalan dengan penelitian yang telah dilakukan oleh Wibisono dkk, (2013) tentang simpuskesmas berbasis Cloud computing (studi kasus di kabupaten demak) yang meyebutkan bahwa pelaksanaan simpus membrikan keuntungan dan kemudahan dalam memberikan pelayanan kepada pasien dalam hal mempercepat pelayan, pencarian dokumen, dan pembuatan laporan serta keseragaman dalam penggunaan sispus di wilayah kabupaten. (Wibisono, Setiawan; Munawaroh 2013) Penyediaan infrastruktur terkait dengan pelaksanaan RME juga menjadi prioritas di beberapa tempat pelayanan kesehatan, seperti di RSUD Yogyakarta (Pratama and Darnoto 2017), dan beberapa rumah sakit lainya. apabila terjadi kendala terkait dengan pelaksanaan simpus yang dilakukan petugas adalah dengan cara menghubungi petugas penanggung jawab dari Dinas Kesehatan Kota Semarang, jika dilihat dari hal ini maka kesiapan infrastruktur di Puskesmas Kedungmundu sudah baik namun masih diperlukan beberapa upaya untuk meningkatkan performa dari sistem yang di terapkan. Dari sisi pendanaan (money) maka pengembangan RME di Puskesmas Kdungmundu tidak mengalami hambatan, karena pengembangan 
sistem di lakukan oleh Dinas Kesehatan setempat.

\section{KESIMPULAN}

Pelaksaan RME di Puskesmas Kedungmundu Kota semarang sudah berjalan dengan baik, karena telah memiliki sumberdaya manusia dan infrastruktur yang mencukupi, terdapat SOP yang mengatur mengenai pelaksanaan RME.

\section{SARAN}

Masih diperlukan pelatihan eabih lanjut bagi petugas rekam medis di Puskesmas tersebt untuk meningkatkan pengetahuan dan ketrampilan petugas. Faktor kesiapan manusia (sosio) dan faktor teknis, menjdai kunci keberhasilan suksesnya migrasi rekam medis kertas menuju rekam medis elektronik. Manfaat yang diperoleh adalah terintegrasinya data dalam satu repository yang memungkinkan untuk dilakukan analisis secara mudah dan cepat dalam pengambilan keputusan.

\section{DAFTAR PUSTAKA}

Azyyati Ridha Alfian, Mega Utami Basra. 2020. "No TitleAnalisis Pelaksanaan E-Puskesmas Di Puskesmas Ikur Koto Padang." Endurance 5(2): 395-402.

Gemala Hatta. 2013. Pedoman Manajemen Informasi Kesehatan Di Sarana Pelayanan Kesehatan (Revisi II). II. Jakarta: UI_perss. Kemenkes RI. 2019. PERATURAN MENTERI KESEHATAN REPUBLIK INDONESIA NOMOR 31 TAHUN 2019 TENTANG SISTEM INFORMASI PUSKESMAS.

-_-. 2020. "Peraturan Menteri Kesehatan Republik Indonesia Nomor 9 Tahun 2020 Tentang Pedoman Pembatasan Sosial Berskala Besar Dalam Rangka
Percepatan Penanganan Corona Virus Disease 2019 (Covid-19)." Kementerian Kesehatan RI.

Kementerian Kesehatan. 2015. "Peraturan Menteri Kesehatan Republik Indonesia Nomor 97 Tahun 2015 Tentang Peta Jalan Sistem Informasi Kesehatan Tahun 2015-2019." Peta Jalan Sistem Informasi Kesehatan Tahun 2015 - 2019: 1-76. http://www.pusdatin. kemkes.go. id/resources/download/pusdatin/ lain-lain/PMK-No-97-Th-2015-

ttg-Peta-Jalan-Sistem-InformasiKesehatan-Tahun-20152019.pdf.

Maha Wirajaya, Made Karma, and $\mathrm{Ni}$ Made Umi Kartika Dewi. 2020. "Analisis Kesiapan Rumah Sakit Dharma Kerti Tabanan Menerapkan Rekam Medis Elektronik." Jurnal Kesehatan Vokasional 5(1): 1.

Pratama, Muhammad Hamdani, and Sri Darnoto. 2017. "ANALISIS STRATEGI PENGEMBANGAN REKAM MEDIS ELEKTRONIK DI INSTALASI RAWAT JALAN RSUD KOTA YOGYAKARTA." Jurnal Manajemen Informasi Kesehatan Indonesia.

Pribadi, Yanuar, Sandra Dewi, and Heru Kusumanto. 2018. "Analisis Kesiapan Penerapan Rekam Medis Elektronik Di Kartini Hospital Jakarta." Jurnal Bidang IImu Kesehatan.

"REKAM MEDIS ELEKTRONIK: TELAAH MANFAAT DALAM KONTEKS PELAYANAN KESEHATAN DASAR." 2013. erawantini, $f$ 1(1): 1-11.

Samandari, Nabil Atta, Wila Chandrawila $\mathrm{S}$, and Agus $\mathrm{H}$. Rahim. 2017. "KEKUATAN PEMBUKTIAN REKAM MEDIS KONVENSIONAL DAN ELEKTRONIK." SOEPRA. 
Kesiapan Petugas Dalam Peralihan ... (Anike Yulis M, Retno Astuti,S, Fitria Wulandari)

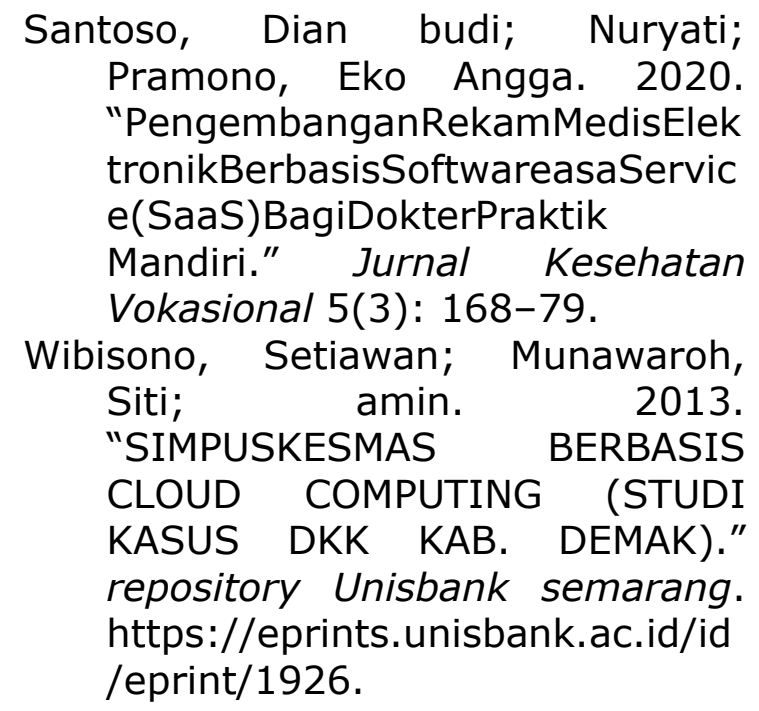

